\title{
Comparison of delignified coconuts waste and cactus for fuel-ethanol production by the simultaneous and semi-simultaneous saccharification and fermentation strategies
}

\author{
Fabiano Avelino Gonçalves ${ }^{\mathrm{a}, \mathrm{b}}$, Héctor A. Ruiz ${ }^{\mathrm{b}, \mathrm{c}}$, Cleitiane da Costa Nogueira ${ }^{\mathrm{a}}$, \\ Everaldo Silvino dos Santos ${ }^{a}$, José A. Teixeira ${ }^{\mathrm{b}}$, Gorete Ribeiro de Macedo ${ }^{\mathrm{a}, *}$ \\ a Laboratory of Biochemical Engineering, Chemical Engineering Department, Federal University of Rio Grande do Norte, 59078-970 Natal, Brazil \\ ${ }^{\mathrm{b}}$ CEB-Centre of Biological Engineering, University of Minho, Campus de Gualtar, 4710-057 Braga, Portugal \\ ${ }^{\mathrm{c}}$ Biorefinery and Food Engineering Laboratory, Food Research Department/School of Chemistry, Autonomous University of Coahuila, Blvd. V. Carranza e Ing. José Cárdenas \\ Valdés, 25280 Saltillo, Coah., Mexico
}

\section{H I G H L I G H T S}

- Sequential Alk- $\mathrm{H}_{2} \mathrm{O}_{2} / \mathrm{NaOH}$

pretreatment was developed.

- FTIR, SEM, X-ray and crystallinity indexes have evidenced modifications in solids.

- Delignified MCF was more susceptible the enzymatic action.

- SSSF strategy allowed to obtain higher ethanol production than SSF.

- Step of presaccharification had a positive effect on the overall ethanol yield.

\section{A R T I C L E I N F O}

\section{Article history:}

Received 20 January 2014

Received in revised form 7 April 2014

Accepted 9 April 2014

Available online 24 April 2014

\section{Keywords:}

Bioethanol

Pretreatment

Coconut fibre

SSSF

Enzymatic hydrolysis
G R A P H I C A L A B S T R A C T

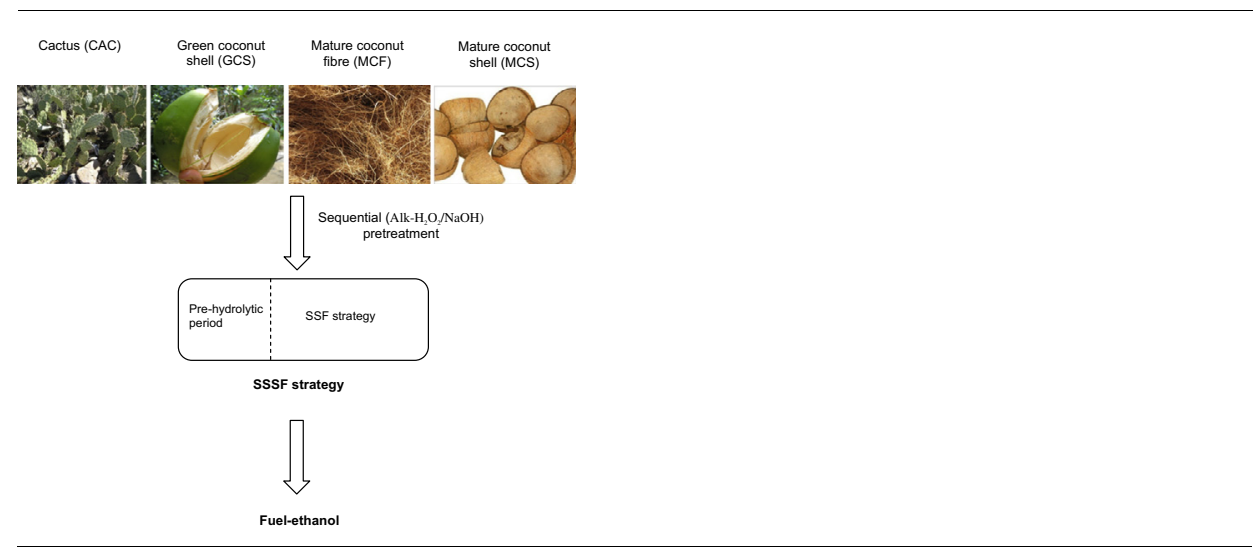

\begin{abstract}
A B S T R A C T
It is of the highest importance to study different alternatives/strategies as simultaneous (SSF) and semisimultaneous (SSSF) saccharification and fermentation process, as well as the prospects of the utilization of lignocellulosic residues as raw materials for fuel-ethanol production. In the first part of this work, different raw materials (cactus (CAC), green coconut shell (GCS), mature coconut fibre (MCF) and mature coconut shell (MCS)) were pretreated by sequential alkaline hydrogen peroxide $\left(\right.$ Alk- $\left.\mathrm{H}_{2} \mathrm{O}_{2}\right)$-sodium hydroxide $(\mathrm{NaOH})$ process. The characterization of the obtained solids by FTIR, SEM, X-ray and crystallinity indexes confirmed the higher susceptibility of these pretreated materials to enzymatic action. These results were further confirmed by the corresponding glucose conversion yields $-68.44 \%, 70.20 \%, 76.21 \%$ and $74.50 \%$ for CAC, GCS, MCF and MCS, respectively. Subsequently, the comparison between SSF and SSSF using Saccharomyces cerevisiae, Pichia stipitis, Zymomonas mobilis and pretreated MCF (selected in the enzymatic hydrolysis step) was done, being shown that a short presaccharification step at $50{ }^{\circ} \mathrm{C}$ for $8 \mathrm{~h}$ in the SSSF had a positive effect on the overall ethanol yield, with an increase from $79.27-84.64 \%$ to $85.04-89.15 \%$. In all the cases, the SSSF strategy allowed the obtention of higher ethanol concentrations than SSF.
\end{abstract}

(c) 2014 Elsevier Ltd. All rights reserved.

\footnotetext{
* Corresponding author. Tel.: +55 843215 3757/3759x229; fax: +55 8432153770.

E-mail address: gomacedo@eq.ufrn.br (G.R.d Macedo).
} 


\section{Introduction}

The use of biofuels, with emphasis on fuel-ethanol is an alternative to mitigate the pressure exerted by fossil fuels and their derivatives. However, fuel-ethanol production from corn, sugarcane and beet may be a problem in the near future due to the food competition in the use of these materials for bioenergy production [1]. One option is the production of cellulosic ethanol from coconut trees, as these crops are distributed in over 200 countries. According to FAO (http://www. www.faostat.org.br), the world production of coconut in 2009 was about 55 million tons, mainly in the Philippines (36\%), Indonesia (28\%) and India (20\%). Brazil is the fourth largest producer of coconut, with a production of about 3 million tons (5.5\%) (http://www.ibge.gov.br). Associated with the large volume coconut production, large amounts of not used agroindustrial waste, suitable to be applied in fuel-ethanol production, are also obtained. Just in Brazil, the production of CAC was 60,000 tons in 2009 , mainly concentrated in the Northeast Region and was fully used in animal feed (http:// www.ibge.gov.br).

Fuel-ethanol production from lignocellulosic materials (LCMs) is complicated due to the recalcitrant nature of the molecules present in these LCMs. In order to make cellulose and hemicellulose more accessible to the attack of cellulases and hemicellulases, a pretreatment is required [1,2]. Pretreatment processes can be physical, chemical, biological or a combination of these methods. The chemical pretreatments used in the delignification of LCMs provide a reduction of the degree of polymerization and crystallinity of cellulose, associated with the swelling of the sample and increase the internal area of LCMs [3]. The application of combined or sequential pretreatments strategies has been shown to be a good way to improve enzymatic hydrolysis and subsequently fuel-ethanol production [3].

The alkaline hydrogen peroxide $\left(\mathrm{Alk}-\mathrm{H}_{2} \mathrm{O}_{2}\right)$ process is based on the pretreatment of LCMs using hydrogen peroxide at alkaline conditions. This process is operated at low temperature and pressure and the peroxide decomposes into oxygen and water and so can be considered a process with a low environmental impact $[4,5]$. According to Gould [6], the use of hydrogen peroxide improves the subsequent delignification of LCMs, because hydrogen peroxide at alkaline conditions promotes the oxidative depolymerization of lignin, due to the break of carbon-carbon linkages in the lignin [7]. Xiang and Lee [8] reported two important factors in the oxidation process: $\mathrm{pH}$ of the reaction and decomposition of hydrogen peroxide. Additionally, the use of sodium hydroxide $(\mathrm{NaOH})$ allows the delignification of LCMs by breaking the ester bonds crosslinking lignin and xylan, increasing the internal surface area [9].

On the other hand, there are different alternatives or strategies in the fermentation process for fuel-ethanol production [10]. During the last years, simultaneous saccharification and fermentation (SSF) has shown to have several advantages compared with separate hydrolysis and fermentation (SHF) in terms of overall ethanol yield and volumetric productivity of ethanol. Moreover, SSF reduces processing time as a consequence of the fast glucose conversion to ethanol by the fermenting microorganisms that reduce the enzyme inhibition due to the presence of sugars. Reduction in equipment costs is also obtained by carrying the hydrolysis and fermentation in a single reactor [11]. However, the difference between the optimal temperature for the enzyme action and microorganism growth is an issue that needs to be solved for an efficient SSF [12]. The operational strategy of semi-simultaneous saccharification and fermentation (SSSF) is a good alternative that includes a short presaccharification period before the SSF process and that has been shown to produce higher ethanol concentration, yield and productivity than SSF and SHF [10]. In this context, the objective of this work was to compare and evaluate the SSSF and SSF strategies for fuel-ethanol production by S. cerevisiae PE2, P. stipitis $\mathrm{Y} 7124$ and $Z$. mobilis B14023 using a selected raw material as the MCF pretreated by the Alk- $\mathrm{H}_{2} \mathrm{O}_{2} / \mathrm{NaOH}$ process.

\section{Materials and methods}

\subsection{Raw materials and chemical characterization}

CAC, GCS, MCF and MCS were obtained from the agroindustries and urban locations in the Northeast of Brazil. The composition of the raw materials was obtained according to Gouveia et al. [13] and Sluiter et al. [14].

\subsection{Pretreatment process}

\subsubsection{Preparation of raw materials before the pretreatment}

The raw materials were washed five times with distilled water at $70{ }^{\circ} \mathrm{C}$ for removal of residual compounds. After this procedure, the LCMs were dried in an oven with air circulation at $40^{\circ} \mathrm{C}$ for $24 \mathrm{~h}$. The LCMs were milled to a particle size of 48 mesh $(0.3 \mathrm{~mm})$.

\subsubsection{Alkaline hydrogen peroxide $\left(\right.$ Alk- $\left.\mathrm{H}_{2} \mathrm{O}_{2}\right)$ pretreatment}

$0.4 \mathrm{~g}$ of LCM were mixed with $31.75 \mathrm{~mL}$ of hydrogen peroxide in a flask with a concentration of $7.35 \%(\mathrm{v} / \mathrm{v})$ at $25^{\circ} \mathrm{C}$ for $1 \mathrm{~h}$ with agitation at $150 \mathrm{rpm}$. The $\mathrm{pH}$ of hydrogen peroxide solution was adjusted to 11.5 with $\mathrm{NaOH}$. The LCM residual solid was separated via vacuum filtration and washed with distilled water [15].

\subsubsection{Delignification process with sodium hydroxide $(\mathrm{NaOH})$}

The Alk- $\mathrm{H}_{2} \mathrm{O}_{2}$ pretreated solids from each LCM were transferred to flasks with a $4 \%(\mathrm{w} / \mathrm{v})$ solution of $\mathrm{NaOH}$. The mixture remained at $100{ }^{\circ} \mathrm{C}$ under agitation at $100 \mathrm{rpm}$ for $1 \mathrm{~h}$. After delignification, the solids were separated from the liquor by filtration. The solids underwent seven washes with distilled water [16].

\subsection{Characterization of delignified pretreated solids}

\subsubsection{Chemical composition after delignification}

The chemical composition was performed as described above (see Section 2.1).

\subsubsection{Fourier-transform infrared (FTIR)}

The FTIR spectra of delignified pretreated solids and untreated LCMs were measured on an FTIR spectrometer (FTLA 2000 series, ABB Bomem Inc., Quebec, Canada). The conditions of analysis were: resolution of $4 \mathrm{~cm}^{-1}$ using 20 scans and frequency range of $400-4000 \mathrm{~cm}^{-1}$. The samples were ground with spectroscopic grade potassium bromide ( $\mathrm{KBr})$.

FTIR analysis was conducted to examine the cellulose structure of delignified pretreated solids and untreated LCMs. Two infrared ratios related to cellulose structure were calculated: (1) $1426 \mathrm{~cm}^{-1} / 896 \mathrm{~cm}^{-1}$, the ratio of peak areas at 1426 and $896 \mathrm{~cm}^{-1}$, which is referred to as crystallinity index [17] or lateral order index (LOI) [18]; (2) $1373 \mathrm{~cm}^{-1} / 2917 \mathrm{~cm}^{-1}$, the ratio of peak areas at 1373 and $2917 \mathrm{~cm}^{-1}$, which is known as total crystallinity index (TCI) [19].

\subsubsection{X-ray diffraction analysis and crystallinity}

Cellulose crystallinity of delignified pretreated solids and untreated LCMs was analyzed in an X-ray diffractometer (Bruker D8 Discover, USA). The operating voltage and current were $40 \mathrm{kV}$ and $40 \mathrm{~mA}$, respectively. The crystallinity index (CI) was defined using the Eq. (1) [3]. 
$\mathrm{CI}=\frac{I_{002}-I_{\mathrm{am}}}{I_{002}} \cdot 100$

where, $I_{002}=$ maximum intensity $\left(2 \theta, 22.6^{\circ}\right)$ of the $(002)$ lattice diffraction; $I_{\mathrm{am}}=$ intensity of the amorphous diffraction $\left(2 \theta, 18.7^{\circ}\right)$.

\subsubsection{Scanning electron microscopy}

The surface of delignified pretreated solids and untreated LCMs was visualized by a scanning electron microscope (Nova NanoSEM 200, Netherlands).

\subsection{Enzymes}

Enzyme solutions, cellulases, $\beta$-glucosidase and hemicellulases (Cellic CTec2) and endoxylanase (HTec2) were kindly supplied by Novozymes A/S (Bagsvaerd, Denmark). The total cellulase activity from Cellic CTec2 was analyzed in accordance with the standard methodology established by Mandels et al. [20]. In a tube were added $0.3 \mathrm{~mL}$ of the commercial enzyme diluted with $1.2 \mathrm{~mL}$ of sodium citrate buffer $0.5 \mu \mathrm{M}$ at $\mathrm{pH} 4.8$ and $50 \mathrm{mg}$ Whatman filter paper No. 1 as substrate. The medium was incubated in a water bath at $50^{\circ} \mathrm{C}$ for $1 \mathrm{~h}$, the glucose liberated was measured using the DNS method. The $\beta$-glucosidase activity was determined for Cellic CTec2. The $\beta$-glucosidase activity was measured by incubating the enzyme solution with $15 \mu \mathrm{M}$ of cellobiose and $50 \mathrm{mM}$ sodium citrate buffer $(\mathrm{pH} 4.8)$ at $50{ }^{\circ} \mathrm{C}$ for $30 \mathrm{~min}$. The reaction was stopped by immersing in boiling water for $5 \mathrm{~min}$. Then, glucose concentration was determined using the GOD-POD method at $25^{\circ} \mathrm{C}$ for $10 \mathrm{~min}$ and the amount of glucose measured spectrophotometrically at $500 \mathrm{~nm}$. One unit of enzyme activity (CBU/ $\mathrm{mL}$ ) was defined as the release of $1 \mu \mathrm{mol}$ of glucose per min. The xylanase activity was determined for HTec2. Reaction mixtures contained $0.1 \mathrm{~mL}$ enzyme and $0.5 \%(\mathrm{w} / \mathrm{v})$ of oat spelts xylan solution in acetate buffer, $\mathrm{pH}$ 5.0. The mixture was incubated at $50{ }^{\circ} \mathrm{C}$ for $10 \mathrm{~min}$. After a predetermined period, the released reducing sugars were quantified by the DNS method [21]. One unit of xylanase activity $(\mathrm{IU} / \mathrm{mL})$ was defined as the amount of enzyme that released $1 \mu \mathrm{mol}$ product per min under the assay conditions. The initial enzyme activities were $126 \mathrm{FPU} / \mathrm{mL}$ of cellulase, $269 \mathrm{CBU} /$ $\mathrm{mL}$ of $\beta$-glucosidase for Cellic CTec 2 kit and $1654 \mathrm{IU} / \mathrm{mL}$ of endoxylanase for Cellic HTec2 kit.

\subsection{Enzymatic hydrolysis}

\subsubsection{Hydrolysis yield}

The obtained delignified pretreated solids were used as substrate in the enzymatic hydrolysis. Enzymatic hydrolysis were performed with $4 \%(\mathrm{w} / \mathrm{v})$ of delignified pretreated solids from each $\mathrm{LCM}$, in an Erlenmeyer flask with a volume of $48 \mathrm{~mL}$ at $50{ }^{\circ} \mathrm{C}$ using Cellic CTec2 and HTec2 with an enzymatic load of 30 FPU, 75 CBU and $130 \mathrm{IU}$ per gram of pretreated solid, in $50 \mathrm{mM}$ sodium citrate buffer with $0.02 \%(\mathrm{w} / \mathrm{v})$ sodium azide to prevent microbial growth. The agitation was maintained at $150 \mathrm{rpm}$ for $96 \mathrm{~h}$. The samples were taken at $6 \mathrm{~h}$ intervals for the first $12 \mathrm{~h}$ and at $12 \mathrm{~h}$ intervals until a total time of $96 \mathrm{~h}[21,22]$. All determinations were performed in duplicate. Sugars concentrations were determined by high performance liquid chromatography (HPLC) (see Section 2.7). The yield of enzymatic hydrolysis was calculated using Eq. (2) [22].

Hydrolysis yield $(\%)=\frac{[\text { glucose }]+1.053[\text { cellobiose }]}{(1.111) f[\text { biomass }]} \cdot 100$

where, glucose $=$ glucose concentration $(\mathrm{g} / \mathrm{L})$; cellobiose $=$ cellobiose concentration $(\mathrm{g} / \mathrm{L})$; biomass $=$ concentration of dry biomass initial of enzymatic hydrolysis $(\mathrm{g} / \mathrm{L}) ; f=$ constitutes of the cellulose fraction of dry biomass $(\mathrm{g} / \mathrm{g}) ; 1.111$ = consists in the conversion factor of cellulose to equivalent glucose; 1.053 = consists in the conversion factor of cellobiose to equivalent glucose.

\subsubsection{Statistical analysis of enzymatic hydrolysis}

The selection of the delignified pretreated solids was performed taking into account the susceptibility to enzymatic hydrolysis. The statistical analysis was carried out using single-factor analysis of variance (ANOVA), while multiple comparison tests were used to determine the statistical significance with a 95\% confidence level. For the data analyses, Statistica software was used.

\subsection{Fermentation process}

\subsubsection{Microorganisms}

Microorganisms P. stipitis, S. cerevisiae and Z. mobilis were used in the fuel-ethanol production. P. stipitis Y7124, Z. mobilis B14023 and $S$. cerevisiae PE2 strains were obtained from microbiological collection of Institute Biotechnology and Bioengineering at the University of Minho. Microorganisms were maintained in Eppendorf at $-80{ }^{\circ} \mathrm{C}$ (glycerol solution at $20 \%$ concentration) and subsequently lyophilized for use as working stock.

\subsubsection{Inoculum preparation}

S. cerevisiae and $P$. stipitis were maintained in Petri dishes containing PDA (potato dextrose agar) culture medium and Z. mobilis was maintained in Petri dishes containing PCA (plate count agar) culture medium at $30^{\circ} \mathrm{C}$ for $24 \mathrm{~h}$. The strains for inoculation were grown in $250 \mathrm{~mL}$ Erlenmeyer flasks with $100 \mathrm{~mL}$ of sterile culture medium containing $50 \mathrm{~g} / \mathrm{L}$ glucose, $1 \mathrm{~g} / \mathrm{L}$ ammonium sulfate, $0.5 \mathrm{~g} / \mathrm{L}$ potassium phosphate, $0.25 \mathrm{~g} / \mathrm{L}$ magnesium sulfate, $10 \mathrm{~g} / \mathrm{L}$ yeast extract and $10 \mathrm{~g} / \mathrm{L}$ peptone at $30^{\circ} \mathrm{C}$ and $200 \mathrm{rpm}$ for $S$. cerevisiae, $250 \mathrm{rpm}$ for $P$. stipitis and $150 \mathrm{rpm}$ for Z. mobilis in an orbital shaker for $12 \mathrm{~h} \mathrm{[23].} \mathrm{For} \mathrm{all} \mathrm{cultures,} \mathrm{the} \mathrm{cell} \mathrm{concentration} \mathrm{in} \mathrm{the}$ inoculum was 2.0 (quantified by measuring the optical density at $600 \mathrm{~nm}$ in a UV-VIS spectrophotometer [12]. Subsequently, the cells were inoculated into $48 \mathrm{~mL}$ culture medium to start the SSF and SSSF processes.

\subsubsection{Simultaneous saccharification and fermentation (SSF)}

SSF experiments were conducted using delignified pretreated solid of MCF in accordance with the NREL standard procedure [22]. $4 \%(\mathrm{w} / \mathrm{v})$ of delignified pretreated solids in $48 \mathrm{~mL}$ of sodium citrate buffer $50 \mathrm{mM}(\mathrm{pH}=5.0)$ were added with Cellic CTec2 and HTec2 with an enzymatic load of 30 FPU, 75 CBU and 130 IU per gram of pretreated solid and supplemented with $1 \mathrm{~g} / \mathrm{L}$ ammonium sulfate, $0.5 \mathrm{~g} / \mathrm{L}$ potassium phosphate, $0.25 \mathrm{~g} / \mathrm{L}$ magnesium sulfate, $2 \mathrm{~g} / \mathrm{L}$ yeast extract and $1 \mathrm{~g} / \mathrm{L}$ peptone [23]. SSF was started by adding enzymes and the microbial strains, incubated for $48 \mathrm{~h}$ at $30^{\circ} \mathrm{C}$ in an orbital shaker at $200 \mathrm{rpm}$ for $S$. cerevisiae, $250 \mathrm{rpm}$ for $P$. stipitis and $150 \mathrm{rpm}$ for $Z$. mobilis. The samples were taken at $0,8,12$, 24,36 and $48 \mathrm{~h}$. Concentrations of ethanol and sugars, glycerol and xylitol were determined by HPLC (see Section 2.7). All determinations were performed in duplicate.

\subsubsection{Semi-simultaneous saccharification and fermentation (SSSF)}

An $8 \mathrm{~h}$ pre-hydrolysis step followed by a $40 \mathrm{~h}$ SSF process was used for SSSF of MCF delignified pretreated solids. After $8 \mathrm{~h}$ of hydrolysis $\left(50^{\circ} \mathrm{C}\right)$, the medium temperature was adjusted to $30{ }^{\circ} \mathrm{C}$ and the SSF step was carried out as previously described (Section 2.6.3).

Ethanol yields from glucose fermentation (Eq. (3)) were calculated assuming that all the potential glucose in the pretreated delignified solids was available for fermentation and that $1 \mathrm{~g}$ of glucose yielded $0.511 \mathrm{~g}$ of ethanol and $1 \mathrm{~g}$ of cellulose gave $0.9 \mathrm{~g}$ of glucose [22]. Furthermore, ethanol yields from xylose fermentation by $P$. stipitis were calculated according to Dowe and McMillan 
[22], but with the inclusion of xylose instead of glucose (Eq. (4)), and considering that $1.0 \mathrm{~g}$ of xylose yielded $0.51 \mathrm{~g}$ of ethanol.

Ethanol yield $(\%)=\frac{[\text { ethanol }]}{[\text { glucose initial }] \cdot 0.51} \cdot 100$

Ethanol yield $(\%)=\frac{[\text { ethanol }]}{[\text { xylose initial }- \text { final xylose }] \cdot 0.51} \cdot 100$

where ethanol = final ethanol concentration $(\mathrm{g} / \mathrm{L})$; glucose initial = initial glucose concentration $(\mathrm{g} / \mathrm{L})$; xylose initial = initial xylose concentration $(\mathrm{g} / \mathrm{L})$; final xylose $=$ final xylose concentration $(\mathrm{g} / \mathrm{L}) ; 0.511=$ is the conversion factor of glucose or xylose to ethanol.

\subsubsection{Statistical analyzes for SSF and SSSF}

Statistical significance was evaluated by Fisher F-test for ANOVA and Student $t$-test, with a confidence level of $95 \%$. Statistical analyzes were performed with the aid of Statistica software.

\subsection{Analysis of samples in high performance liquid chromatography (HPLC)}

All the samples were centrifuged and filtered through a $0.2 \mu \mathrm{m}$ sterile membrane filter for glucose, xylose, glycerol, ethanol and xylitol quantification. Chromatographic separation was performed using a Metacarb $87 \mathrm{H}$ column $(300 \times 7.8 \mathrm{~mm}$, Varian, USA) under the following conditions: mobile phase $0.005 \mathrm{~mol} / \mathrm{L}$ sulfuric acid, flow rate $0.7 \mathrm{~mL} / \mathrm{min}$ and column temperature $60^{\circ} \mathrm{C}$ using a Jasco chromatograph 880-PU pump (Jasco, Tokyo, Japan) equipped with a Jasco 830-IR refraction-index detector (Jasco, Tokyo, Japan) and a Jasco AS-2057 Plus auto sampler (Jasco, Tokyo, Japan).

Table 1

Chemical composition (\% dry weight) of untreated, alkaline hydrogen peroxide (Alk$\mathrm{H}_{2} \mathrm{O}_{2}$ ) pretreated and sequential alkaline hydrogen peroxide $\left(\right.$ Alk- $\left.\mathrm{H}_{2} \mathrm{O}_{2}\right)$-sodium hydroxide $(\mathrm{NaOH})$ pretreatment for MCF, GCS, MCS and CAC.

\begin{tabular}{|c|c|c|c|}
\hline \multicolumn{4}{|c|}{ Mature coconut fibre } \\
\hline Components & Untreated & Alk- $\mathrm{H}_{2} \mathrm{O}_{2}$ & Alk- $\mathrm{H}_{2} \mathrm{O}_{2} / \mathrm{NaOH}$ \\
\hline Cellulose & $31.60 \pm 0.51$ & $41.53 \pm 0.89$ & $51.80 \pm 0.78$ \\
\hline Hemicellulose & $26.33 \pm 0.89$ & $28.40 \pm 0.74$ & $25.81 \pm 0.54$ \\
\hline Insoluble lignin & $25.02 \pm 0.78$ & $16.51 \pm 0.26$ & $8.83 \pm 0.18$ \\
\hline Soluble lignin & $1.67 \pm 0.19$ & $0.83 \pm 0.15$ & $0.09 \pm 0.01$ \\
\hline Extractable & $5.44 \pm 0.24$ & $0.36 \pm 0.13$ & $0.05 \pm 0.04$ \\
\hline Ash & $3.31 \pm 0.32$ & $2.92 \pm 0.22$ & $2.98 \pm 0.14$ \\
\hline \multicolumn{4}{|c|}{ Green coconut shell } \\
\hline Cellulose & $32.88 \pm 0.88$ & $51.58 \pm 0.87$ & $54.14 \pm 0.14$ \\
\hline Hemicellulose & $26.50 \pm 0.45$ & $27.94 \pm 0.90$ & $28.36 \pm 0.28$ \\
\hline Insoluble lignin & $25.44 \pm 0.75$ & $9.07 \pm 0.04$ & $7.64 \pm 0.43$ \\
\hline Soluble lignin & $1.44 \pm 0.27$ & $0.61 \pm 0.01$ & $0.25 \pm 0.01$ \\
\hline Extractable & $3.27 \pm 0.15$ & $0.77 \pm 0.28$ & $0.26 \pm 0.45$ \\
\hline Ash & $4.34 \pm 0.20$ & $1.95 \pm 0.06$ & $1.07 \pm 0.07$ \\
\hline \multicolumn{4}{|c|}{ Mature coconut shell } \\
\hline Cellulose & $30.47 \pm 0.86$ & $37.24 \pm 0.69$ & $53.88 \pm 0.41$ \\
\hline Hemicellulose & $25.42 \pm 0.29$ & $29.29 \pm 0.74$ & $23.02 \pm 0.59$ \\
\hline Insoluble lignin & $31.04 \pm 0.18$ & $18.11 \pm 0.26$ & $9.33 \pm 0.21$ \\
\hline Soluble lignin & $2.11 \pm 0.09$ & $1.44 \pm 0.14$ & $0.89 \pm 0.03$ \\
\hline Extractable & $2.71 \pm 0.31$ & $0.84 \pm 0.04$ & $0.53 \pm 0.03$ \\
\hline Ash & $4.84 \pm 0.09$ & $4.34 \pm 0.27$ & $3.80 \pm 0.07$ \\
\hline \multicolumn{4}{|l|}{ Cactus } \\
\hline Cellulose & $38.33 \pm 0.64$ & $44.00 \pm 0.79$ & $54.91 \pm 0.72$ \\
\hline Hemicellulose & $22.19 \pm 0.59$ & $21.39 \pm 0.75$ & $17.65 \pm 0.29$ \\
\hline Insoluble lignin & $19.51 \pm 0.29$ & $13.66 \pm 0.45$ & $8.74 \pm 0.11$ \\
\hline Soluble lignin & $1.39 \pm 0.13$ & $1.27 \pm 0.24$ & $0.71 \pm 0.06$ \\
\hline Extractable & $5.82 \pm 0.24$ & $1.92 \pm 0.05$ & $0.48 \pm 0.05$ \\
\hline Ash & $6.64 \pm 0.21$ & $8.80 \pm 0.30$ & $8.77 \pm 0.12$ \\
\hline
\end{tabular}

\section{Results and discussion}

\subsection{Compositions of raw materials}

The composition of raw materials used (\% dry weight) is presented in Table 1. The initial moisture content of CAC, GCS, MCF and MCS was $12.60 \%, 8.99 \%, 6.14 \%$ and $5.52 \%$, respectively. The component present in higher amounts was cellulose with $38.33 \%$, $32.88 \%, 31.6 \%$ and $30.47 \%$ for CAC, GCS, MCF and MCS, respectively, followed by hemicellulose and insoluble lignin, except for MCS, where lignin has a higher percentage than hemicellulose. Apart from the fact there are few reports regarding the composition of CAC, GCS, MCF and MCS. The composition of CAC depends on age, time of collecting and soil properties [24]. Vaithanomsat et al. [25] reported the chemical composition of coconut husk as: cellulose (39.31\%), hemicellulose (16.15\%) and lignin (29.79\%). Overall, the chemical composition of these LCMs suggests their adequacy for the fuel-ethanol production.

\subsection{Effect of sequential alkaline hydrogen peroxide $\left(\right.$ Alk- $\left.-\mathrm{H}_{2} \mathrm{O}_{2}\right)-$ sodium hydroxide $(\mathrm{NaOH})$ process}

The purpose of using Alk- $\mathrm{H}_{2} \mathrm{O}_{2}$ and $\mathrm{NaOH}$ was to improve the efficacy of the delignification process in the LCMs. After Alk- $\mathrm{H}_{2} \mathrm{O}_{2}$ treatment, the obtained solid yields were $64.15 \%, 55.30 \%, 51.95 \%$ and $59.70 \%$ for CAC, GCS, MCF and MCS, respectively. In Table 1 the chemical composition of the different LCMs after Alk- $\mathrm{H}_{2} \mathrm{O}_{2}$ pretreatment is presented. The main effect of this process was the reduction of the lignin content in the pretreated LCMs, in comparison to the untreated LCMs. The observed reduction was $28.56 \%$, $63.99 \%, 35.03 \%$ and $41.02 \%$ for CAC, GCS, MCF and MCS, respectively. In a recent work, Da Costa et al. [26] reported a $43.76 \%$ reduction in lignin for cashew apple bagasse pretreated with Alk$\mathrm{H}_{2} \mathrm{O}_{2}$ at $35^{\circ} \mathrm{C}$ for $24 \mathrm{~h}$ with hydrogen peroxide at a concentration of $4.3 \%(\mathrm{v} / \mathrm{v})$ and Gould [6] reported that wheat straw was partially delignified using Alk- $\mathrm{H}_{2} \mathrm{O}_{2}$. Moreover, Gould [6] indicated that the delignification reaction is strongly dependent upon the $\mathrm{pH}$ of the reaction mixture with an optimum at $\mathrm{pH}$ 11.5-11.6. Ayeni et al. [27] used alkaline peroxide assisted wet air oxidation pretreatment of LCMs and obtained an up to $60 \%$ enrichment of cellulose with $80 \%$ and $17 \%$ reduction of hemicellulose and lignin, respectively. These results are in agreement with those reported in this work, evidencing the reduction of lignin in the solid after Alk- $\mathrm{H}_{2} \mathrm{O}_{2}$ pretreatment. However, a different result was reported by Brígida et al. [28] as a $4.31 \%$ pulp decrease and a $3.31 \%$ lignin increase in the coconut fiber pretreated with Alk- $\mathrm{H}_{2} \mathrm{O}_{2}(5.4 \%(\mathrm{v} / \mathrm{v})$ hydrogen peroxide at $85^{\circ} \mathrm{C}$ for $2 \mathrm{~h}$ ).

The chemical composition of the different LCMs (\% dry weight) after the application of the sequential Alk $-\mathrm{H}_{2} \mathrm{O}_{2} / \mathrm{NaOH}$ treatment is shown in the Table 1 . The obtained solid yields are $50.90 \%, 38.40 \%$, $46.35 \%, 49.76 \%$ for CAC, GCS, MCF and MCS, respectively, with corresponding reductions of $54.78 \%, 70.64 \%, 66.57 \%$ and $69.17 \%$ in the lignin content. The highest content of cellulose after this sequential process was $54.91 \%$ for CAC. This effect can be explained by the solubilization of lignin, revealing that the cellulose was almost not affected by the sequential process and consequently a pretreated solid with increased cellulose content was obtained. These results are in agreement with the ones obtained by Chen et al. [29] that reported that more than $95 \%$ of cellulose was conserved in alkaline pretreatment. In this work, for all the different materials considered, cellulose content increased and lignin content decreased while a reduction in hemicellulose was observed only for CAC, MCF and MCS. According to Siqueira et al. [30], removal of lignin increases the enzymatic hydrolysis of sugarcane bagasse, resulting in a larger conversion of cellulose to glucose. Presented results 
suggest that the use of sequential Alk- $\mathrm{H}_{2} \mathrm{O}_{2} / \mathrm{NaOH}$ pretreatment increases the selectivity of lignin degradation, in comparison to the Alk- $\mathrm{H}_{2} \mathrm{O}_{2}$ pretreatment.

In what concerns cellulose and hemicellulose recovered, the obtained values were, respectively, $75.98 \%$ and $68.27 \%$ for MCF pretreated by Alk- $\mathrm{H}_{2} \mathrm{O}_{2}$ and $56.03 \%$ and $45.43 \%$ for the Alk- $\mathrm{H}_{2} \mathrm{O}_{2} /$ $\mathrm{NaOH}$ pretreatment. In the case of GCS, the equivalent values were $81.50 \%$ and $76.32 \%, 54.77 \%$ and $49.60 \%$; for MCS were $81.96 \%$ and $63.49 \%, 59.86 \%$ and $41.97 \%$; and for CAC were $66.40 \%$ and $59.63 \%$, $50.08 \%$ and $36.87 \%$.

\subsection{Characterization of delignified pretreated solids}

\subsubsection{X-ray diffraction analysis and crystallinity}

The cellulose contained in the delignified pretreated solids has a crystalline region (highly ordered) and the applied pretreatment results in a region with different properties for each of the LCMs. The diffraction peaks around $15-16^{\circ}$ and $21-22^{\circ}(2 \theta)$ are characteristics of the cellulose from LCMs. The crystallinity indexes are presented in Fig. 1A-D.

A
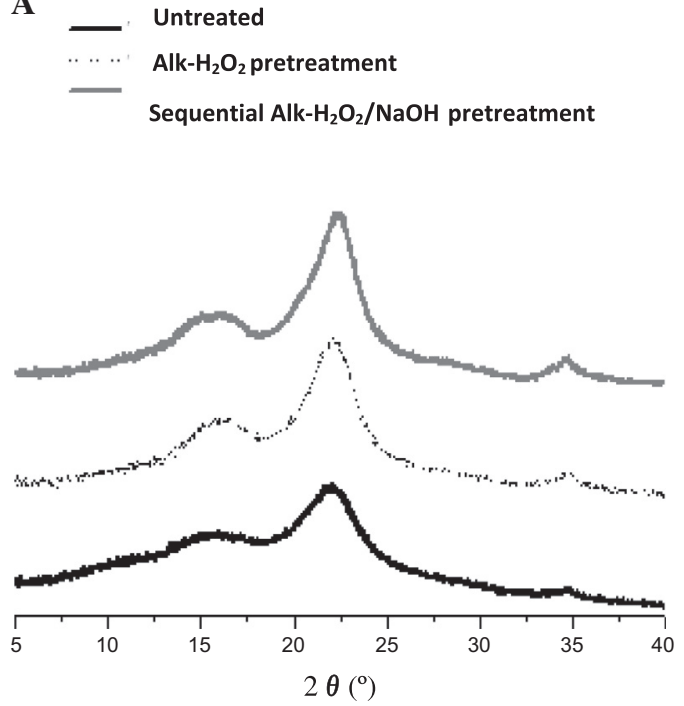

C Untreated

-... Alk- $\mathrm{H}_{2} \mathrm{O}_{2}$ pretreatment Sequential Alk- $\mathrm{H}_{2} \mathrm{O}_{2} / \mathrm{NaOH}$ pretreatment

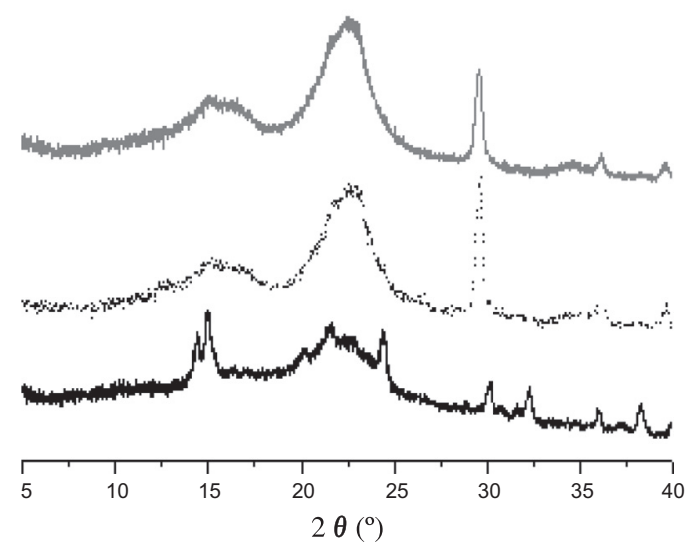

The crystallinity indexes of untreated LCMs were $34.34 \%$, $28.03 \%, 29.31 \%$ and $23.20 \%$ for MCF, MCS, GCS and CAC, respectively (Table 2). After the Alk- $\mathrm{H}_{2} \mathrm{O}_{2}$ pretreatment and sequential Alk- $\mathrm{H}_{2} \mathrm{O}_{2} / \mathrm{NaOH}$ pretreatment for MCF, GCS and CAC an increase in the crystallinity indexes was observed. For MCF, the increase was from $50.79 \%$ to $55.73 \%$; for GCS from $49.18 \%$ to $49.89 \%$ and for CAC from $46.09 \%$ to $48.43 \%$. For MCS a decrease from $55.98 \%$ to $53.77 \%$ was observed. This effect can be explained by the removal amorphous lignin and hemicellulose that causes an increase in the crystallinity while the swelling of cellulose in hydrogen peroxide solution softened the lignocellulosic structure and hence a decrease the crystallinity occurs [31].

\subsubsection{Fourier-transform infrared (FTIR)}

The infrared spectroscopy analysis was carried out with the purpose of obtaining information about the chemical groups present in the delignified pretreated solids, mainly the formation of free radicals in the polymer chains, indicating the existence of broken covalent bonds, a method commonly used by its simplicity and efficiency in biological analysis. The FTIR spectra in the region between 400 and $4000 \mathrm{~cm}^{-1}$ of LCMs are presented in Fig. 2 .

B
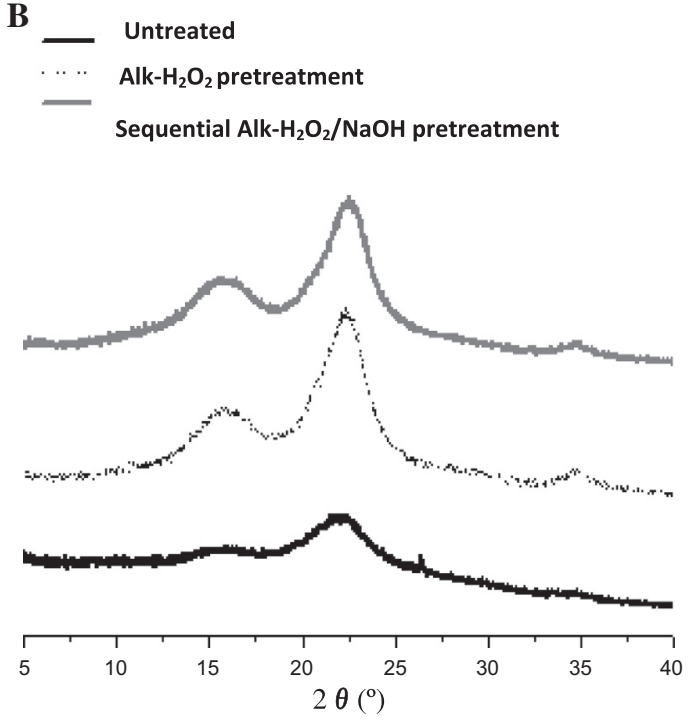

D Untreated

-... Alk- $\mathrm{H}_{2} \mathrm{O}_{2}$ pretreatment

Sequential Alk- $\mathrm{H}_{2} \mathrm{O}_{2} / \mathrm{NaOH}$ pretreatment

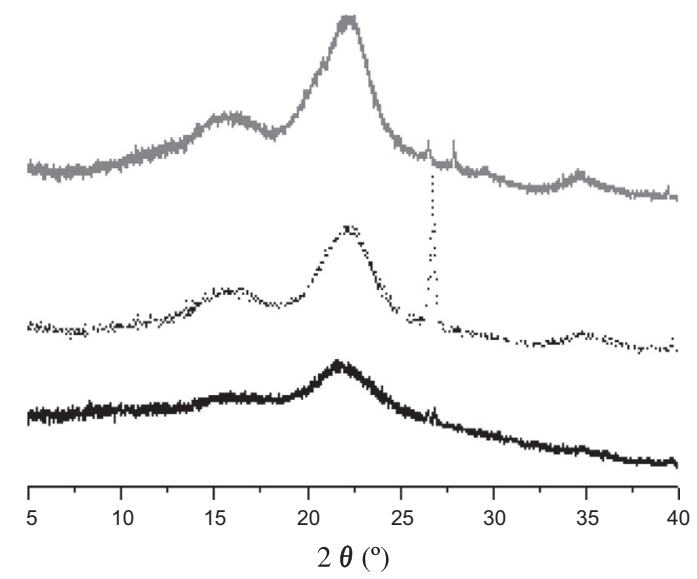

Fig. 1. X-ray diffraction curves of untreated, Alk- $\mathrm{H}_{2} \mathrm{O}_{2}$ pretreatment and sequential Alk- $\mathrm{H}_{2} \mathrm{O}_{2} / \mathrm{NaOH}$ pretreatment: (A) MCF, (B) GCS, (C) MCS and (D) CAC. 
Table 2

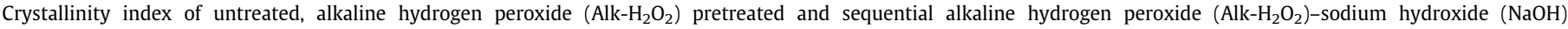
pretreatment for MCF, GCS, MCS and CAC.

\begin{tabular}{|c|c|c|c|c|c|c|c|c|c|}
\hline \multirow[t]{2}{*}{ Lignocellulosic material } & \multicolumn{3}{|l|}{ LOI (FTIR) } & \multicolumn{3}{|l|}{ TCI (FTIR) } & \multicolumn{3}{|c|}{ CI (X-ray diffraction) } \\
\hline & Untreated & Alk- $\mathrm{H}_{2} \mathrm{O}_{2}$ & Alk- $\mathrm{H}_{2} \mathrm{O}_{2} / \mathrm{NaOH}$ & Untreated & Alk- $\mathrm{H}_{2} \mathrm{O}_{2}$ & Alk- $\mathrm{H}_{2} \mathrm{O}_{2} / \mathrm{NaOH}$ & Untreated & Alk- $\mathrm{H}_{2} \mathrm{O}_{2}$ & Alk- $\mathrm{H}_{2} \mathrm{O}_{2} / \mathrm{NaOH}$ \\
\hline Cactus & 0.679 & 0.908 & 0.924 & 0.816 & 0.944 & 1.014 & 0.232 & 0.461 & 0.484 \\
\hline Green coconut shell & 0.852 & 0.910 & 0.913 & 0.861 & 1.039 & 1.056 & 0.293 & 0.492 & 0.499 \\
\hline Mature coconut fibre & 0.888 & 0.934 & 0.957 & 0.919 & 1.014 & 1.073 & 0.343 & 0.508 & 0.557 \\
\hline Mature coconut shell & 0.783 & 0.942 & 0.937 & 0.831 & 1.067 & 1.047 & 0.280 & 0.560 & 0.538 \\
\hline
\end{tabular}

LOI: lateral order index based on FTIR $\left(1426 / 896 \mathrm{~cm}^{-1}\right)$.

TCI: total crystallinity index based on FTIR $\left(1373 / 2917 \mathrm{~cm}^{-1}\right)$.

$\mathrm{CI}$ : crystallinity index based on X-ray diffraction.
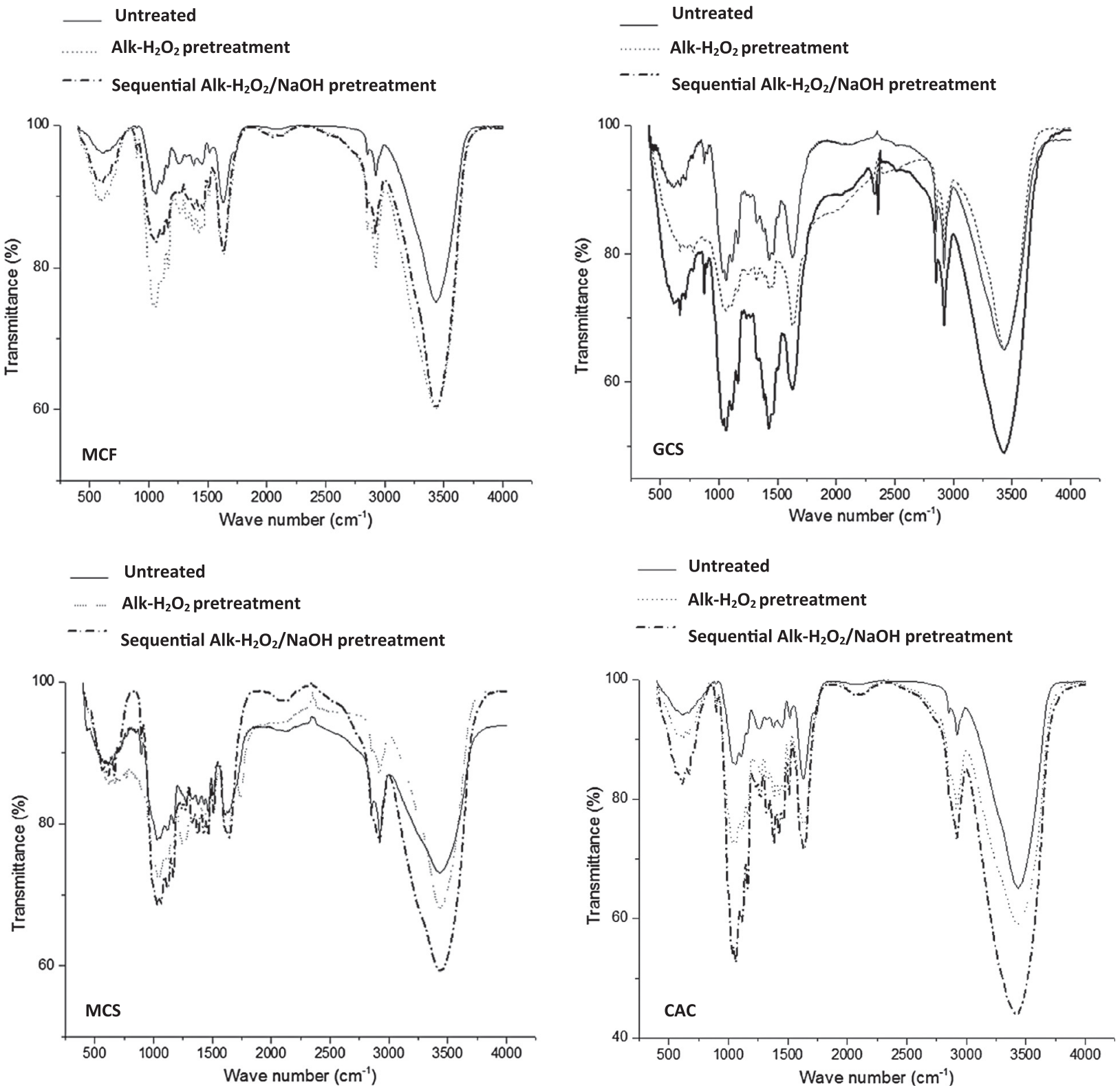

Fig. 2. FTIR spectra of untreated, Alk- $\mathrm{H}_{2} \mathrm{O}_{2}$ pretreatment and sequential Alk- $\mathrm{H}_{2} \mathrm{O}_{2} / \mathrm{NaOH}$ pretreatment for MCF, GCS, MCS and CAC.

Several relevant changes can be observed in the delignified pretreated solids compared to untreated LCMs. The presence of a peak at $1238 \mathrm{~cm}^{-1}$ relates to esters, ethers and phenolic groups and is attributed mainly to the presence of waxes in the epidermal tissue of the LCM, its disappearance after the pretreatment, representing the removal of these waxes fibers. Similar results were reported by Brígida et al. [28] in pretreated green coconut fiber. The carboxyl band $\left(1636 \mathrm{~cm}^{-1}\right)$ in the spectrum of the untreated samples is related to the carboxyl groups of pectin associated with the cellulose fibers. 
At $1254 \mathrm{~cm}^{-1}$ the absence of the peak corresponding to the double bond between carbon and oxygen lignin in the delignified pretreated solids, is an indication of the absence or reduction of lignin in the LCMs. The peaks at wavelengths 1030, 1241, 1360, 1405, 1430 and $1500 \mathrm{~cm}^{-1}$ are related to lignin [7]. The pretreated LCMs showed reductions in the intensity or absence of these peaks, indicating the rupture of lignin links [7]. These data that corroborates the reduction of lignin content in LCMs is supported by the presented SEM images.

The hemicellulose pattern shows characteristic peaks at wavelengths of $897,1043,1164,1248$ and $1728 \mathrm{~cm}^{-1}$. These hemicellulose peaks were observed in untreated and pretreated LCMs, [29] and are in agreement with the chemical composition data presented in Table 1 . The band ranging between 1370 and $1390 \mathrm{~cm}^{-1}$ where no peak is observed refers to a symmetrical structure and an asymmetrical deformation of cellulose and hemicellulose and may be indicative of a greater exposure of cellulose and hemicellulose on the fiber surface [28]. This is relevant information concerning the enzymatic digestibility of the LCMs.

The peak observed at a wavelength $3340 \mathrm{~cm}^{-1}$ is related to hydrogen bonding $(\mathrm{OH})$ and indicates the stretching vibration of the structure of cellulose and lignin of the LCM. The band at $3400 \mathrm{~cm}^{-1}$ corresponds to the stretching of the hydroxyl and phenol groups at the LCMs and the observed peak increase after pretreatment indicates a reduction in the content of these groups in the obtained materials. These results may be related to the reduction of the degree of hydrogen bonding, resulting in the reduction of the superficial polarity of the fiber.

Overall, FTIR analysis corroborates the results on the chemical composition of delignified pretreated solids presented in Table 1, that demonstrate a reduced lignin content, while retaining hemicellulose and cellulose.

The crystallinity index $(\mathrm{CI})$ was also obtained from values contained in the wavelengths of $1426 / 896 \mathrm{~cm}^{-1}$ and the total crystallinity index (TCI) from the values contained in the wavelengths of $1373 / 2917 \mathrm{~cm}^{-1}$ for both untreated and pretreated LCMs (Table 2). The $1426 \mathrm{~cm}^{-1}$ band represents $\mathrm{CH}_{2}$ scissoring motion [32] and the $896 \mathrm{~cm}^{-1}$ band indicates the vibrational mode involving carbon and four atoms attached to it, which is characteristic of $\beta$-anomers or $\beta$-linked glucose polymers [32]. The $1373 \mathrm{~cm}^{-1}$ band is for $\mathrm{CH}$ bending mode [19] and the $2917 \mathrm{~cm}^{-1}$ band represents $\mathrm{C}-\mathrm{H}$ and $\mathrm{CH}_{2}$ stretching, which is unaffected by changes in crystallinity [19]. Therefore, higher values of LOI and TCI are indicative of biomass with a higher crystallinity and a more ordered structure of cellulose. The results obtained for LOI (FTIR) and TCI (FTIR) and presented in Table 2, show increased crystallinity indexes for the pretreated LCMs in comparison to the untreated ones. These results agree with the $\mathrm{CI}$ vales obtained by X-ray diffraction.

\subsubsection{Scanning electron microscopy (SEM)}

Differences in fiber structure between untreated, Alk- $\mathrm{H}_{2} \mathrm{O}_{2}$ and sequential Alk- $\mathrm{H}_{2} \mathrm{O}_{2} / \mathrm{NaOH}$ pretreated LCMs are presented in Fig. 3A-L. The untreated LCMs showed the fibers rigid surfaces intact and highly ordered (Fig. 3A, D, G and J). However, SEM images of Alk- $\mathrm{H}_{2} \mathrm{O}_{2}$ (Fig. $3 \mathrm{~B}, \mathrm{E}, \mathrm{H}$ and $\mathrm{K}$ ) and Alk- $\mathrm{H}_{2} \mathrm{O}_{2} / \mathrm{NaOH}$ pretreated (Fig. 3C, F, I and L) LCMs clearly show modified structures and a destruction of the fibers, fiber separation and the appearance of disordered fibers. These structural features may provide greater susceptibility of pretreated LCMs to enzymatic action.

\subsection{Enzymatic hydrolysis for the selection of pretreated delignified material for further fermentation}

The enzymatic hydrolysis of $\mathrm{Alk}-\mathrm{H}_{2} \mathrm{O}_{2} / \mathrm{NaOH}$ pretreated LCMs will enable the selection of solid with the highest conversion yield and initial hydrolysis rate to be used in the fermentation stage. The conversion yields (\%) of CAC, GCS, MCF and MCS were $68.44 \%$ (0.50 g glucose $/ g$ LCM), $70.20 \%$ (0.56 g glucose $/ g$ LCM), $76.21 \%$ ( $0.59 \mathrm{~g}$ glucose $/ \mathrm{g} \mathrm{LCM}$ ) and $74.50 \%$ ( 0.57 g glucose/g LCM), respectively, after $96 \mathrm{~h}$ (Fig. 4A). These results demonstrate the susceptibility of the LCMs pretreated by Alk- $\mathrm{H}_{2} \mathrm{O}_{2} / \mathrm{NaOH}$ to enzymatic attack. In a recent work, Rabelo et al. [15] reported a high glucose yield after enzymatic hydrolysis using sugarcane bagasse pretreated with Alk- $\mathrm{H}_{2} \mathrm{O}_{2}(7.35 \%(\mathrm{v} / \mathrm{v})$ of hydrogen peroxide for $1 \mathrm{~h}$ at $25^{\circ} \mathrm{C}$ ). Gupta and Lee [7] also concluded that the use of hydrogen peroxide (5\%) in alkaline solution (5\%) on hybrid poplar at low temperature improved the delignification and the enzymatic hydrolysis, similar to the results presented in this work [7].

The results obtained in the enzymatic hydrolysis were evaluated by ANOVA and significant differences in the level of confidence of $95 \%$ were observed, being the highest sugar yields obtained for MCF.

Regarding the maximum initial hydrolysis rate $(d G / d t)$, measured during the first $12 \mathrm{~h}$ (the slope of glucose concentration vs. time) (Fig. 4B) the highest, initial hydrolysis rate was obtained for MCF $(1.49 \mathrm{~g} /(\mathrm{L} \mathrm{h}))$ and MCS $(1.43 \mathrm{~g} /(\mathrm{L} \mathrm{h}))$, while lower values were reported for GCS $(1.28 \mathrm{~g} /(\mathrm{L} \mathrm{h}))$ and CAC $(1.04 \mathrm{~g} /(\mathrm{L} \mathrm{h}))$. In comparison, Ruiz et al. [2] reported initial hydrolysis rate of wheat straw pretreated by autohydrolysis of $0.47 \mathrm{~g} /(\mathrm{L} \mathrm{h})$ using $30 \mathrm{FPU} / \mathrm{g}$ of cellulose. These results demonstrate the susceptibility of the pretreated LCMs to enzymatic attack.

The results obtained during enzymatic hydrolysis (see Fig. 4) emphasize that the highest conversion of pretreated LCMs into glucose occurred in the LCMs with higher crystallinity indexes (see Table 2). According to Kim et al. [33], the increased crystallinity can provide higher digestibility of LCM due to the higher exposure of the crystalline part on the surface of the LCM.

\subsection{Fermentation process for fuel-ethanol production}

SSF and SSSF strategies were evaluated using P. stipitis Y7124, Z. mobilis $\mathrm{B} 14023, S$. cerevisiae PE2 and MCF pretreated by the sequential Alk- $\mathrm{H}_{2} \mathrm{O}_{2} / \mathrm{NaOH}$ process. The pretreated $\mathrm{MCF}$ was selected based on the enzymatic hydrolysis yield and initial hydrolysis rate. The performance of the fermentation strategies was assessed by conversion yield (\%) and volumetric productivity of ethanol $(\mathrm{g} /(\mathrm{L} \mathrm{h}))[11]$.

\subsubsection{Simultaneous saccharification and fermentation (SSF) and semi-} simultaneous saccharification and fermentation (SSSF)

The values obtained in the fuel-ethanol production by SSF using S. cerevisiae PE2, P. stipitis Y7124 and Z. mobilis B14023 are shown in Fig. 5A-C, respectively. The obtained ethanol concentrations were $8.44 \mathrm{~g} / \mathrm{L}, 9.12 \mathrm{~g} / \mathrm{L}$ and $8.27 \mathrm{~g} / \mathrm{L}$ for $S$. cerevisiae PE2, P. stipitis Y7124 and Z. mobilis B14023, respectively and the process was completed after $48 \mathrm{~h}$. Concerning ethanol yield, the results are presented in Table 3. The ethanol yield for S. cerevisiae PE2 was $84.64 \%$ ( $0.43 \mathrm{~g}$ ethanol/g sugar) and the volumetric productivity of ethanol $0.18 \mathrm{~g} /(\mathrm{L} \mathrm{h})$, while for P. stipitis Y7124 and Z. mobilis B14023 the obtained values were $79.27 \%$ ( $0.40 \mathrm{~g}$ ethanol/g sugar) and $81.71 \%$ ( $0.42 \mathrm{~g}$ ethanol $/ \mathrm{g}$ sugar) for ethanol yield and $0.19 \mathrm{~g} /(\mathrm{L} \mathrm{h})$ and $0.17 \mathrm{~g} /(\mathrm{L} \mathrm{h})$ for volumetric productivity of ethanol, respectively (Table 3 ). These results indicate that the glucose obtained from the enzymatic hydrolysis of pretreated MCF may be fermented to ethanol by S. cerevisiae PE2, P. stipitis Y7124 and Z. mobilis B14023, the kinetic profiles having a similar pattern for glucose consumption, with a rapid glucose consumption during the initial $24 \mathrm{~h}$ (Fig. 5A-C). All microorganisms proved to suitable for the fermentation of sugars into ethanol.

In a recent work, Chaudhary et al. [34] produced fuel-ethanol through of a sequential alkaline and acid pretreatment using Kans Grass biomass as substrate and $P$. stipitis as microorganism, 

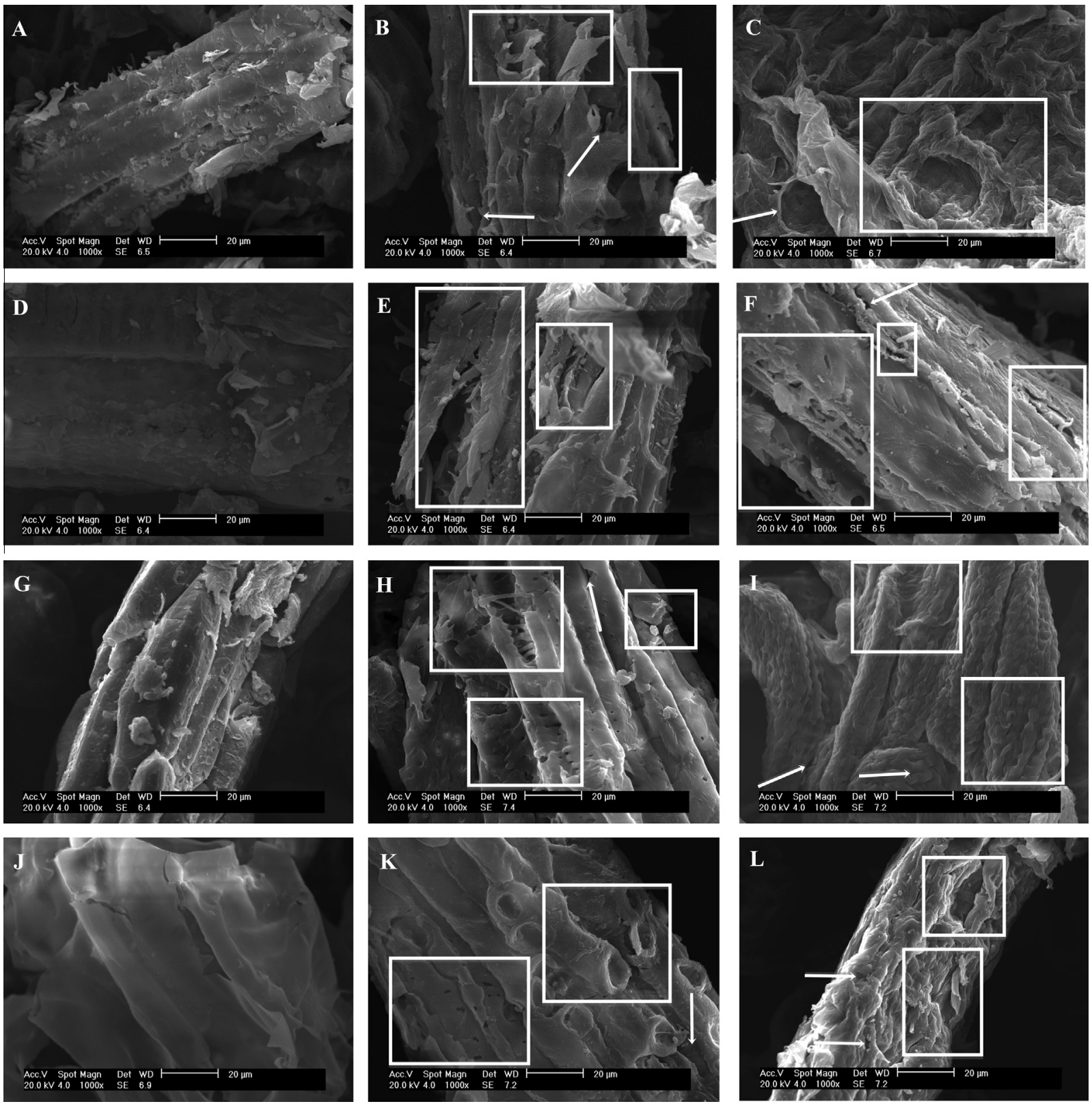

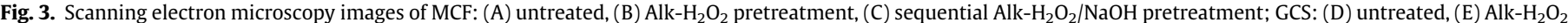

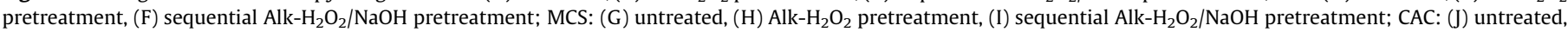
(K) Alk- $\mathrm{H}_{2} \mathrm{O}_{2}$ pretreatment, and (L) sequential Alk- $\mathrm{H}_{2} \mathrm{O}_{2} / \mathrm{NaOH}$ pretreatment. High porosity area, matrix separation and exposition fibers (white square).

reporting a volumetric productivity of ethanol of $0.22 \mathrm{~g} /(\mathrm{L} \mathrm{h})$. In this work, using $P$. stipitis Y7124, the obtained volumetric productivity of ethanol was $0.19 \mathrm{~g} /(\mathrm{L} \mathrm{h})$. Vaithanomsat et al. [25] studied the efficiency fuel-ethanol production using SSF and SHF processes with $S$. cerevisiae on coconut husk pretreated with $\mathrm{NaOH}$ as raw material and reported a conversion above $85 \%$ in both cases, a result similar to the one reported in this work where an ethanol yield of $84.64 \%$ ) was obtained.

In the same Fig. $(5 \mathrm{~A}-\mathrm{C})$ are reported the equivalent values for ethanol fermentation using the SSSF strategy and the same LCM. Being $9.32 \mathrm{~g} / \mathrm{L}$ and $89.15 \%$ (0.45 $\mathrm{g}$ ethanol/g sugar), $10.17 \mathrm{~g} / \mathrm{L}$ and $85.04 \%$ (0.43 $\mathrm{g}$ ethanol $/ \mathrm{g}$ sugar), $8.91 \mathrm{~g} / \mathrm{L}$ and $85.65 \%(0.44 \mathrm{~g}$ ethanol/g sugar) for production and yield of ethanol by the $S$. cerevisiae PE2, P. stipitis Y7124 and Z. mobilis B14023, respectively, after $48 \mathrm{~h}$ (Table 3). The highest volumetric ethanol productivity was $0.21 \mathrm{~g} /$ (L h) for P. stipitis Y7124, whereas the lowest was $0.19 \mathrm{~g} /(\mathrm{L} \mathrm{h})$ for $S$. cerevisiae PE2 and Z. mobilis B14023. All the experiments had a similar pattern for glucose concentration during the initial $8 \mathrm{~h}$ with a gradually decrease with increasing time (Fig. 5A-C). Results obtained for ethanol production and yield with the SSSF strategy are slightly higher compared with SSF (see Table 3). Moreover, higher volumetric productivities were obtained for SSSF. The higher fermentative efficiency for SSSF may be explained by the application of the short presaccharification period [35], which can enhance the conversion of cellulose to glucose and, in sequence, to ethanol.

In a recent work, Franco et al. [36] carried out the SSSF process ( $24 \mathrm{~h}$ of presaccharification and $24 \mathrm{~h}$ of SSF) using delignified Pinus radiata and $S$. cerevisiae, resulting in an ethanol yield and ethanol production of $90.0 \%$ and $15.5 \mathrm{~g} / \mathrm{L}$, respectively. These results are in agreement with the results obtained in this work for SSSF (ethanol yield between $85.65 \%$ and $89.15 \%$ ). Martín et al. [37] 

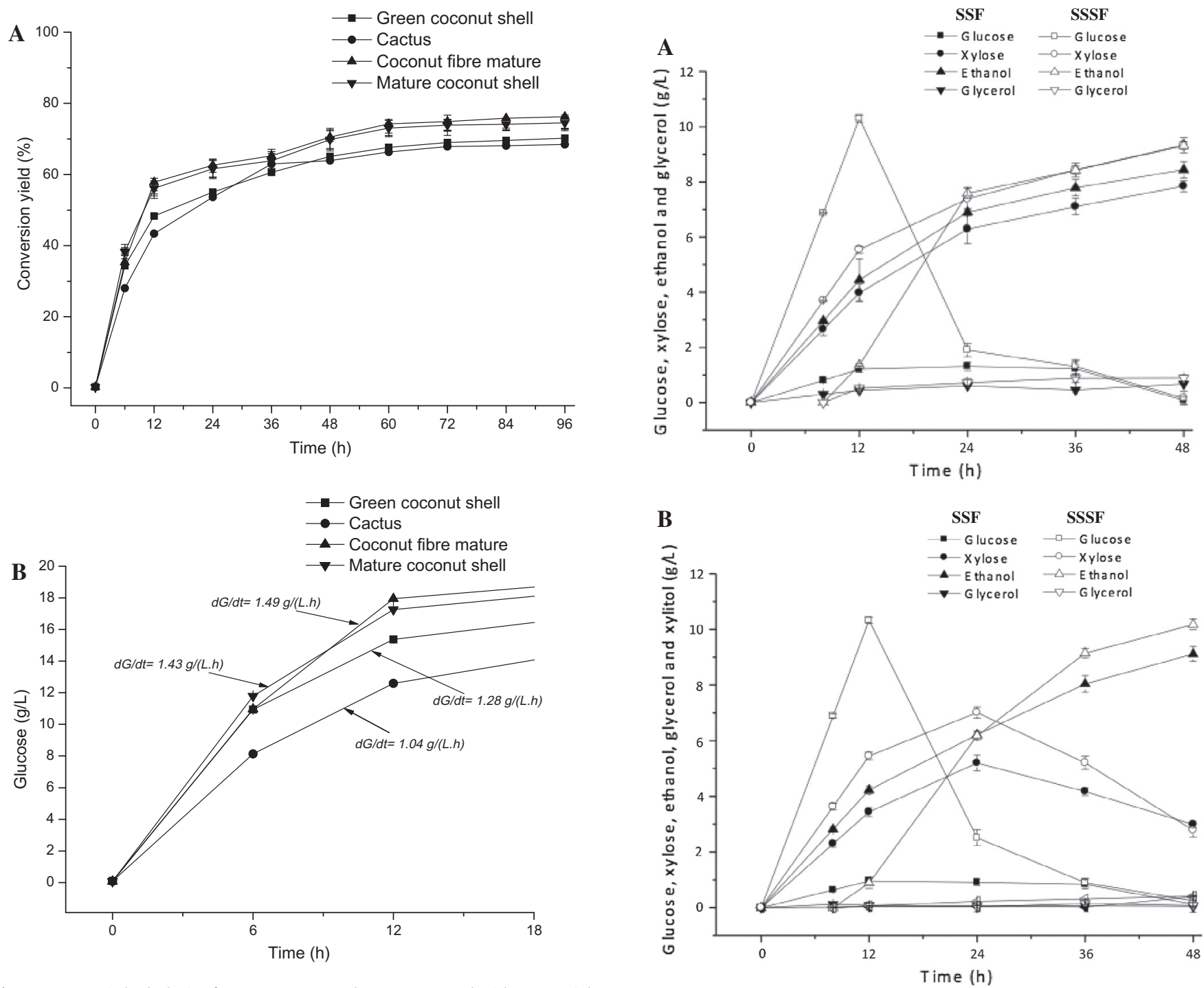

Fig. 4. Enzymatic hydrolysis of GCS, CAC, MCF and MCS pretreated with sequential Alk- $\mathrm{H}_{2} \mathrm{O}_{2} / \mathrm{NaOH}$ process. (A) Conversion yield\%, and (B) Initial hydrolysis rate at $12 \mathrm{~h}$.

reported that the presaccharification led to a rapid liquefaction and a good mixing was attained after $6 \mathrm{~h}$, when the SSF process started. Santos et al. [38] carried out the SSSF process with $6 \mathrm{~h}$ of presaccharification period at $50{ }^{\circ} \mathrm{C}$ and subsequently the SSF at $37^{\circ} \mathrm{C}$ using a delignified sugarcane bagasse as raw material and $S$. cerevisiae UFPEDA 1238 , and the results were $27.71 \mathrm{~g} / \mathrm{L}$ and $0.77 \mathrm{~g} /$ ( $\mathrm{L} h$ ) of ethanol production and volumetric productivity of ethanol, respectively. According to Souza et al. [12], the presaccharification has a possible positive effect, increasing the ethanol yield and volumetric productivity of ethanol. Additionally, they concluded that the use of a thermotolerant yeast and presaccharification stage are key points to increase yields in the SSF process for fuel-ethanol production.

SHF, SSF and SSSF strategies were compared by Mesa et al. [39] that reported that from one ton of sugarcane bagasse it is possible to obtain 192, 172 and $198 \mathrm{~L}$ of ethanol from SHF, SSF and SSSF, respectively. They concluded that SSSF is the best process strategy based on ethanol yield and volume of ethanol. Santos et al. [23] compared different process configurations for SSF and SSSF and reported that the highest cellulose to ethanol conversion and maximum ethanol productivities were completed with presaccharification prior to SSF. In this work, SSSF allowed to obtain a higher ethanol production than SSF.

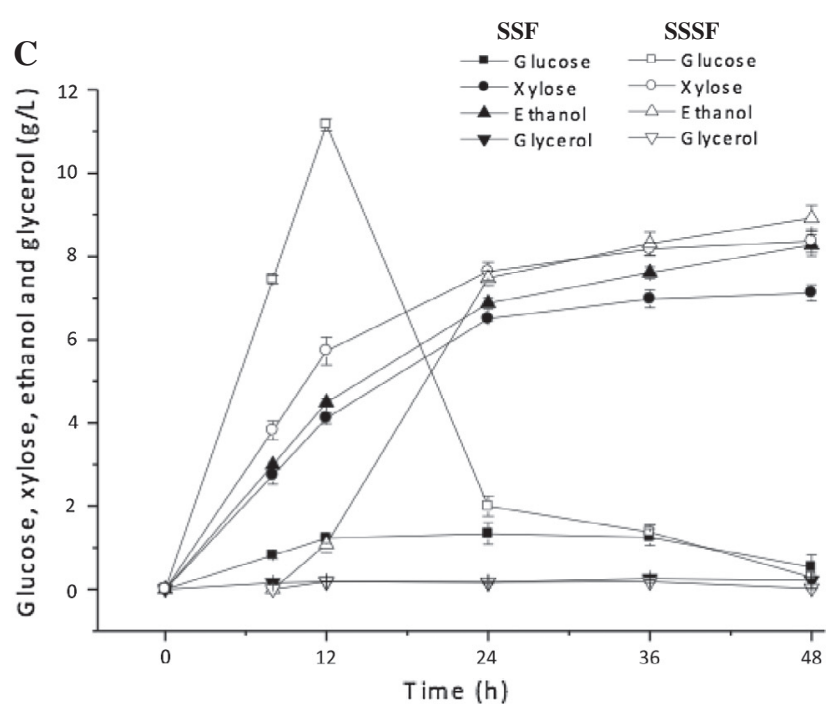

Fig. 5. Kinetics profiles of SSF and SSSF strategy using MCF pretreated with the sequential Alk- $\mathrm{H}_{2} \mathrm{O}_{2} / \mathrm{NaOH}$ process (A) S. cerevisiae PE2, (B) P. stipitis $\mathrm{Y} 7124$, and (C) Z. mobilis B14023.

The fuel-ethanol production by $S$. cerevisiae, $P$. stipitis and $Z$. mobilis using SSSF and SSF was evaluated statistically using t-test 
Table 3

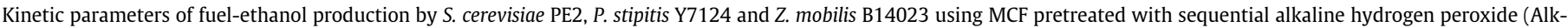
$\mathrm{H}_{2} \mathrm{O}_{2}$ )-sodium hydroxide $(\mathrm{NaOH})$ as raw material in SSF and SSSF strategy.

\begin{tabular}{|c|c|c|c|c|c|c|c|}
\hline \multirow{2}{*}{$\begin{array}{l}\text { Operational strategy } \\
\text { SSF }\end{array}$} & \multirow{2}{*}{$\begin{array}{l}\text { Microorganism } \\
\text { S. cerevisiae }\end{array}$} & \multicolumn{2}{|c|}{ Ethanol yield (\%) } & \multicolumn{2}{|c|}{ Ethanol concentration $(\mathrm{g} / \mathrm{L})$} & \multicolumn{2}{|c|}{ Ethanol productivity $(\mathrm{g} /(\mathrm{L} \mathrm{h}))$} \\
\hline & & 84.64 & \pm 0.61 & 8.44 & \pm 0.06 & 0.18 & \pm 0.01 \\
\hline & P. stipitis & 79.27 & \pm 1.56 & 9.12 & \pm 0.18 & 0.19 & \pm 0.00 \\
\hline & Z. mobilis & 81.71 & \pm 0.60 & 8.27 & \pm 0.06 & 0.17 & \pm 0.00 \\
\hline \multirow[t]{3}{*}{ SSSF } & S. cerevisiae & 89.15 & \pm 0.73 & 9.32 & \pm 0.08 & 0.19 & \pm 0.01 \\
\hline & P. stipitis & 85.04 & \pm 0.54 & 10.17 & \pm 0.06 & 0.21 & \pm 0.00 \\
\hline & Z. mobilis & 85.65 & \pm 1.02 & 8.91 & \pm 0.11 & 0.19 & \pm 0.00 \\
\hline
\end{tabular}

and ANOVA (confidence level 95\%). The fuel-ethanol production by the different microorganisms using SSF showed significant differences, when evaluated by the ANOVA. Similar results were also obtained when SSSF was applied. The comparison between results obtained by $S$. cerevisiae using SSF and $S$. cerevisiae using SSSF showed significant differences, when evaluated by the $t$-test. Similar results were also showed by the P. stipitis and Z. mobilis strains.

Glycerol is also formed as a byproduct in ethanol production during fermentation under anaerobic and aerobic growth conditions, and its can be influenced by microbial growth and several environmental factors as osmotic pressure [40]. In this work, the fermentations carried out by S. cerevisiae PE2, P. stipitis Y7124 and Z. mobilis B14023 in SSF and SSSF strategies presented minimal glycerol concentrations (Fig. 5A), in agreement with literature results for SSSF $[10,38]$. Moreover, no production of xylitol by P. stipitis Y7124 was observed for both SSF and SSSF strategies.

\section{Conclusion}

The present work was based on the evaluation of four raw materials (CAC, GCS, MCF and MCS) as promising materials for fuel-ethanol production. The effect of Alk- $\mathrm{H}_{2} \mathrm{O}_{2}$ and Alk- $\mathrm{H}_{2} \mathrm{O}_{2}$ / $\mathrm{NaOH}$ pretreatments on solids properties was evaluated by FTIR, SEM, X-ray and crystallinity indexes determination. Moreover, sequential Alk- $\mathrm{H}_{2} \mathrm{O}_{2} / \mathrm{NaOH}$ pretreatment showed to be a suitable technology for generation of cellulose-enriched solids and MCF was selected for further fermentation taking into account its higher susceptibility to enzymatic hydrolysis. The short presaccharification at $50{ }^{\circ} \mathrm{C}$ for $8 \mathrm{~h}$ in SSSF had a positive effect on the overall ethanol yield, an increase from $79.27-84.64 \%$ to $85.04-89.15 \%$ being observed for the different microbial strains considered. The SSSF strategy allowed for the obtention of a higher ethanol production than SSF.

\section{Acknowledgments}

The authors gratefully acknowledge the Brazilian research funding agencies CNPq and CAPES for financial support.

\section{References}

[1] Gonçalves FA, Sanjinez-Argandoña EJ, Fonseca GG. Utilization of agroindustrial residues and municipal waste of plant origin for cellulosic ethanol production. J Environ Protect 2011;2:1303-9.

[2] Ruiz HA, Vicente AA, Teixeira JA. Kinetic modeling of enzymatic saccharification using wheat straw pretreated under autohydrolysis and organosolv process. Ind Crops Prod 2012;36:100-7.

[3] Ruiz HA, Ruzene DS, Silva DP, da Silva FFM, Vicente AA, Teixeira JA. Development and characterization of an environmentally friendly process sequence (autohydrolysis and organosolv) for wheat straw delignification. Appl Biochem Biotechnol 2011;164:629-41.

[4] Rabelo SC, Maciel Filho R, Costa AC. A comparison between lime and alkaline hydrogen peroxide pretreatments of sugarcane bagasse for ethanol production. Appl Biochem Biotechnol 2008;148:45-58.

[5] Banerjee G, Car S, Liu T, Williams DL, Meza SL, Walton JD, et al. Scale-up and integration of alkaline hydrogen peroxide pretreatment, enzymatic hydrolysis, and ethanolic fermentation. Biotechnol Bioeng 2012;109:922-31.

[6] Gould JM. Studies on the mechanism of alkaline peroxide delignification of agricultural residues. Biotechnol Bioeng 1985;27:225-31.
[7] Gupta R, Lee YY. Pretreatment of corn stover and hybrid poplar by sodium hydroxide and hydrogen peroxide. Biotechnol Prog 2010;4:1180-6.

[8] Xiang Q, Lee YY. Oxidative cracking of precipitated hardwood lignin by hydrogen peroxide. Appl Biochem Biotechnol 2000;84:153-62.

[9] Kang KE, Jeong G, Park D. Pretreatment of rapeseed straw by sodium hydroxide. Bioprocess Biosyst Eng 2012;35:705-13.

[10] Shen J, Agblevor FA. Ethanol production of semi-simultaneous saccharification and fermentation from mixture of cotton gin waste and recycled paper sludge. Bioprocess Biosyst Eng 2011;34:33-43.

[11] Shen J, Agblevor FA. Modeling semi-simultaneous saccharification and fermentation of ethanol production from cellulose. Biomass Bioenerg 2010;34:1098-107.

[12] de Souza CJA, Costa DA, Rodrigues MQRB, dos Santos AF, Lopes MR, Abrantes $A B P$, et al. The influence of presaccharification, fermentation temperature and yeast strain on ethanol production from sugarcane bagasse. Bioresour Technol 2012;109:63-9.

[13] Gouveia ER, Nascimento RT, Souto-Maior AM, Rocha GJM. Validation of methodology for the chemical characterization of sugar cane bagasse. Quim Nova 2009;32:1500-3.

[14] Sluiter A, Hames B, Hyman D, Payne C, Ruiz R, Scarlata C, et al. Determination of total solids in biomass and total dissolved solids in liquid process samples. Golden (Colorado): National Renewable Energy Laboratory; 2008.

[15] Rabelo SC, Amezquita Fonseca NA, Andrade RR, Maciel Filho R, Costa AC. Ethanol production from enzymatic hydrolysis of sugarcane bagasse pretreated with lime and alkaline hydrogen peroxide. Biomass Bioenerg 2011;25:2600-7.

[16] Santos JRA, Gouveia ER. Bioethanol production from sugarcane bagasse. Rev Bras Prod Agroind 2009;11:27-33.

[17] O'Connor RT, DuPré EF, Mitcham D. Applications of infrared absorption spectroscopy to investigations of cotton and modified cottons. Text Res J 1958;28:382-92.

[18] Hurtubise FG, Krassig H. Classification of fine structural characteristics in cellulose by infared spectroscopy. Use of potassium bromide pellet technique. Anal Chem 1960;32:177-81.

[19] Nelson ML, O'Connor RT. Relation of certain infrared bands to cellulose crystallinity and crystal lattice type. Part II. A new infrared ratio for estimation of crystallinity in celluloses I and II. J Appl Polym Sci 1964;8:1325-41.

[20] Mandels M, Andreotti R, Roche C. Measurement of saccharifying cellulase. Biotechnol Bioeng Symp 1976;6:21-3.

[21] Miller GL. Use of dinitrosalicylic acid reagent for determination of reducing sugars. Anal Chem 1959;31:426-8.

[22] Dowe N, McMillan J. SSF experimental protocols-lignocellulosic biomass hydrolysis and fermentation. NERL analytical procedure. Colorado (Golden): National Renewable Energy Laboratory; 2001.

[23] Santos JRA, Souto-Maior AM, Gouveia ER, Martin C. Comparison of SHF and SSF processes from sugar cane bagasse for ethanol production by Saccharomyces cerevisiae. Quim Nova 2010;33:904-8.

[24] Oliveira MA, Rodrigues C, dos Reis EM, Nozaki J. Production of fungal protein by solid substrate fermentation of cactus cereus peruvianus and Opuntia ficus indica. Quim Nova 2001;24:307-10.

[25] Vaithanomsat P, Apiwatanapiwat W, Chumchuent N, Kongtud W, Sundhrarajun S. The potential of coconut husk utilization for bioethanol production. Kasetsart J 2011;45:159-64.

[26] da Costa JA, Júnior JEM, Gonçalves LRB, Rocha MVP. Alkaline hydrogen peroxide pretreatment of cashew apple bagasse for ethanol production: study of parameters. Bioresour Technol 2013:139:249-56.

[27] Ayeni AO, Hymore FK, Mudliar SN, Deshmukh SC, Satpute DB, Omoleye JA, et al. Hydrogen peroxide and lime based oxidative pretreatment of wood waste to enhance enzymatic hydrolysis for a biorefinery: process parameters optimization using response surface methodology. Fuel 2013;106:187-94.

[28] Brígida AIS, Calado VMA, Gonçalves LRB, Coelho MAZ. Effect of chemical treatments on properties of green coconut fiber. Carbohydr Polym 2010;79:832-8.

[29] Chen Y, Stevens AM, Zhu Y, Holmes J, Xu H. Understanding of alkaline pretreatment parameters for corn stover enzymatic saccharification. Biotechnol Biofuels 2013;6:1-10.

[30] Siqueira G, Várnai A, Ferraz A, Milagres AMF. Enhancement of cellulose hydrolysis in sugarcane bagasse by the selective removal of lignin with sodium chlorite. Appl Energy 2013;102:399-402.

[31] Wei C, Cheng C. Effect of hydrogen peroxide pretreatment on the structural features and the enzymatic hydrolysis of rice straw. Biotechnol Bioeng 1985;27:1418-26. 
[32] Nelson ML, O'Connor RT. Relation of certain infrared bands to cellulose crystallinity and crystal latticed type. Part I. Spectra of lattice types I, II, III and of amorphous cellulose. J Appl Polym Sci 1964;8:1311-24.

[33] Kim SB, Lee SJ, Jang EJ, Han SO, Park C, Kim SW. Sugar recovery from rice straw by dilute acid pretreatment. J Ind Eng Chem 2012:18:183-7.

[34] Chaudhary G, Singh LS, Ghosh S. Alkaline pretreatment methods followed by acid hydrolysis of Saccharum spontaneum for bioethanol production. Bioresour Technol 2012;124:111-8.

[35] Hoyer K, Galbe M, Zacchi G. The effect of prehydrolysis and improved mixing on high-solids batch simultaneous saccharification and fermentation of spruce to ethanol. Process Biochem 2013;48:289-93.

[36] Franco H, Ferraz A, Milagres AMF, Carvalho W, Freer J, Baeza J, et al. Alkaline sulfite/anthraquinone pretreatment followed by disk refining of Pinus radiate and Pinus caribaea wood chips for biochemical ethanol production. J Chem Technol Biotechnol 2012;87:651-7.
[37] Martín C, Thomsen MH, Hauggaard-Nielsen H, Thomsen AB. Wet oxidation pretreatment, enzymatic hydrolysis and simultaneous saccharification and fermentation of clover-ryegrass mixtures. Bioresour Technol 2008;99:8777-82.

38] Santos JRA, Lucena MS, Gusmão NB, Gouveia ER. Optimization of ethano production by Saccharomyces cerevisiae UFPEDA 1238 in simultaneous saccharification and fermentation of delignified sugarcane bagasse. Ind Crop Prod 2012;36:584-8.

[39] Mesa L, González E, Romero I, Ruiz E, Cara C, Castro E. Comparison of process configurations for ethanol production from two-step pretreated sugarcane bagasse. Chem Eng J 2011;175:185-91.

[40] Öhgren K, Vehmaanperä J, Siika-Aho M, Galbe M, Viikari L, Zacchi G. High temperature enzymatic prehydrolysis prior to simultaneous saccharification and fermentation of steam pretreated corn stover for ethanol production. Enzyme Microbiol Technol 2007;40:607-13. 